
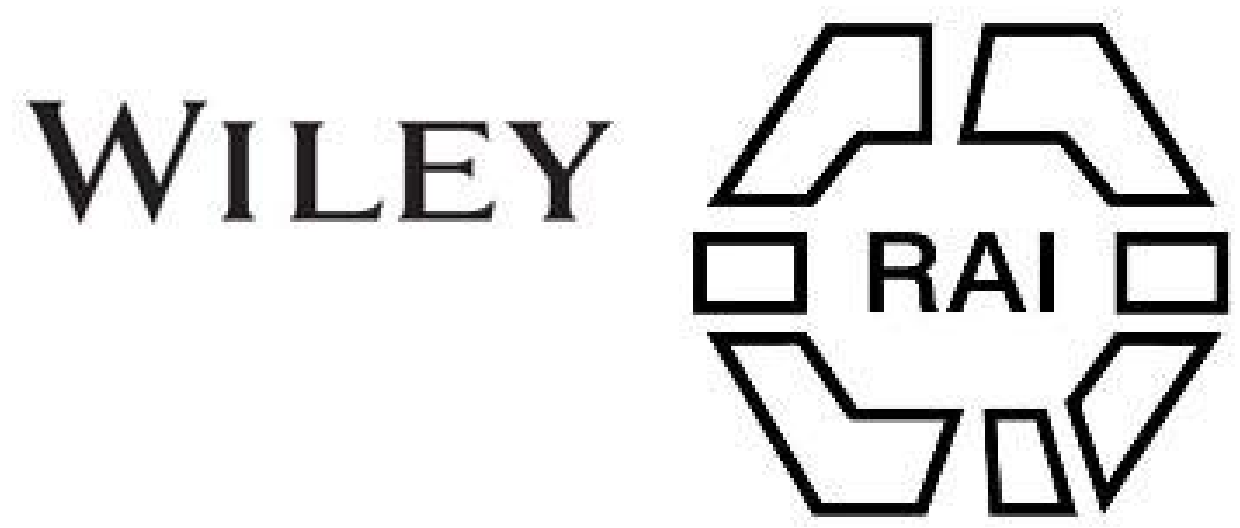

\title{
41. Outrigger Canoes in the Congo
}

\section{Author(s): E. Torday}

Source: Man, Vol. 18 (May, 1918), p. 72

Published by: Royal Anthropological Institute of Great Britain and Ireland

Stable URL: http://www.jstor.org/stable/2787375

Accessed: 09-04-2016 12:05 UTC

\section{Your use of the JSTOR archive indicates your acceptance of the Terms \& Conditions of Use, available at}

http://about.jstor.org/terms

JSTOR is a not-for-profit service that helps scholars, researchers, and students discover, use, and build upon a wide range of content in a trusted digital archive. We use information technology and tools to increase productivity and facilitate new forms of scholarship. For more information about JSTOR, please contact support@jstor.org.

Wiley, Royal Anthropological Institute of Great Britain and Ireland are collaborating with JSTOR to digitize, preserve and extend access to Man 
It is quite posstble that the Maltese cart ruts date from this latter period. The present Maltese carts are probably of an archæan type; I have seen the same type in Egypt and in Italy, and I have seen similar cart ruts in the streets of Pompeii. Professor Cole has suggested that as Malta stands on a shallow platform it once was a much bigger island than at present, and possibly with a moist climate supported a large population.

Before concluding I will mention that Professor Zammit has suggested that the "ruts" were cut first by men in the rock so as to make a track for the wheels. I cannot agree with this idea, for in many places I saw ruts cut a few inches deep, and then the wheels had shifted and cut another rut parallel to the first and only a few inches away from it, and between the two sets often could be seen a narrow flange of stone standing up. A large lumbering waggon with big wheels would easily shift its course when being dragged along, and cut new ruts alongside of the old. Such a condition is of common occurrence, and in some places two or three parallel ruts can be found, all more or less shallow. With regard to the age of the ruts, I think it will be conceded that if they were cut by large, heavy wheels, 5 to 6 feet in diameter, those wheels must have been shod with iron, and on consulting with an eminent Egyptologist, I find that although small pieces of iron have been found in the remains of the early dynasties, iron was not in common use till 600 B.c. From this it would appear that the Maltese cart ruts date either from Roman times or since then, and I think that the early middle ages is the most likely period.

\section{Note.}

Huntingdon traces a high fluvial period before the Christian era, falling then to an interfluvial dry period from 400 to 600 A.D., during which the conditions were dryer than the present day. This latter, after 600 A.D., was in turn followed by a moist period, which possibly oscillated to dry again during the centuries 1,000 to 1,200 , and again became moist in the later Middle Ages. The interfluvial period, 400 to 600 A.D., would probably be the cause of the Decline and Fall of the Roman Empire, and the consequent drifting of power to the north. The cart ruts were possibly formed during Roman times.

E. G. FENT.ON.

\section{Africa, Central: Canoes.}

Outrigger Canoes in the Congo. By E. Torday.

Among my notes, the publication of which has been delayed by the war

(there are two volumes of them in the printer's hands-in Brussels), there is one referring to outriggers observed in the Congo by Captain Hilton Simpson and myself ; Dr. Haddon's paper on "The Outrigger Canoe of East Africa" seems to make it imperative that I should mention it now. In a Baboma village, situated on the Kasai river, two days' navigation above the mouth of the Kwilu, we saw some dıg-outs transporting some enormous nets to the fishing ground. The nets were stretched between sticks and carried upright, not unlike sails; to counterbalance their weight the canoes were provided witb outriggers on one side; these were not improvised, but specially carved for the purpose. We photographed them, but the plates unfortunately perished on their way to Europe. It is, however, possible that Professor Starr, of Chicago, who visited the same region, may possess photographs of them, but this may depend on the season when he travelled there, as fishing with nets of this kind is not practised all the year round. I was also told by the natives that they manufactured canoes of wickerwork covered with hide, and that Professor Starr was fortunate enough to purchase one of these. I suppose these "canoes" were simply outriggers. The Baboma are frequently mistaken for Basongo Meno, the inhabitants of the other bank of the river. E. TORDAY. 